Research Article

\title{
Calculative Width of Pile Foundation on Slope Based on Particle Image Velocimetry (PIV)
}

\author{
Shun Kang $\mathbb{D}^{1,2,3,4}$ Qihua Zhao, ${ }^{3,4}$ and Changwu Liu $\mathbb{D}^{1,2}$ \\ ${ }^{1}$ State Key Laboratory of Hydraulics and Mountain River Engineering, Sichuan University, Chengdu, Sichuan 610065, China \\ ${ }^{2}$ College of Water Resource and Hydropower, Sichuan University, Chengdu, Sichuan 610065, China \\ ${ }^{3}$ State Key Laboratory of Geohazard Prevention and Geoenvironment Protection, Chengdu University of Technology, Chengdu, \\ Sichuan 610059, China \\ ${ }^{4}$ College of Environment and Civil Engineering, Chengdu University of Technology, Chengdu, Sichuan 610059, China
}

Correspondence should be addressed to Changwu Liu; liuchangwu@scu.edu.cn

Received 21 November 2019; Revised 20 September 2020; Accepted 30 September 2020; Published 13 October 2020

Academic Editor: Francesco Canestrari

Copyright (c) 2020 Shun Kang et al. This is an open access article distributed under the Creative Commons Attribution License, which permits unrestricted use, distribution, and reproduction in any medium, provided the original work is properly cited.

The calculative width directly affecting the horizontal bearing capacity of the pile is an important parameter of the horizontal loaded pile foundation and its effective value will change with the variation of slope angle. In order to research the effect of slope on calculative width, 4 groups of model test under static lateral loading with different slope angles were carried out indoor. Based on the PIV system, the horizontal diffusion angle was obtained by the quantitative analysis of the vectorial displacement field of soil around the pile. The calculative width of pile under 4 slopes was then calculated based on the Horizontal Diffusion Principle. Compared with numerical simulation and full-scale test, calculative width based on Horizontal Diffusion Principle is greater than that based on the code of China (JGJ94-2008) and it decreases by about $3.3 \mathrm{~m}$ by every $10^{\circ}$ increase of slope. After correcting the calculative width based on Horizontal Diffusion Principle, $m$-value that can characterize the horizontal resistance of the pile is greater than that based on the code of China (JGJ94-2008); the average difference of two $m$-values is about $75 \mathrm{MN} / \mathrm{m}^{4}$. Slope has a strong weakening effect on $m$-value. These conclusions provide a certain reference for the selection of calculative width in engineering.

\section{Introduction}

The weakening effect of slope on the horizontal bearing stability of pile foundation is a hotspot in engineering $[1,2]$. The change of calculative width with the slope has been considered as the major reason for this weakening effect. As an important factor affecting its horizontal bearing capacity, the calculative width is directly related to the scale of the soil exerted resistance, and it plays a key role in bearing capacity design.

Pile-soil interaction under lateral load has been widely studied but mainly on the horizontal ground $[3,4]$. Pile foundation shows different stress characteristics under slope, for example, the change of effective calculating width [5]. As an important parameter to measure the stress characteristics of the pile, effective calculative width plays a key role in horizontal bearing capacity [6]. The reason is that the skin friction along the pile will drive more soil to bear lateral load because the soil around the pile will diffuse at a certain angle, which has been called horizontal diffusion angle $[7,8]$. This phenomenon will make the actual width bearing load bigger than geometric width. Stress characteristics during pile-soil interaction can be researched by Static Lateral Loading Test [9] and PIV [10, 11]. There are many indexes that can be used to illustrate the change of lateral bearing capacity of the pile, like $m$-value $[12,13]$ and $p-y$ curve $[14,15]$.

This paper mainly considers the skin friction along the single pile to carry out the horizontal static load model test of single pile. In order to study the effect of slope on calculative width of pile foundation, effective calculative width was obtained based on vectorial displacement field of soil by PIV 
system under the slopes of $0^{\circ}, 15^{\circ}, 30^{\circ}$, and $45^{\circ}$. Comparing indoor model test with numerical test and full-scale test, the reduction effect of the calculative width of pile foundation with the slope is quantified. Furthermore, $m$-value was used as a characterization parameter to illustrate the effect of the effective calculative width on the horizontal bearing capacity of the pile.

\section{Indoor Physical Simulation}

2.1. Design of Tests. Based on the full-scale test of the single pile under horizontal static load in Malcolm-Selgu transmission line, Sichuan, China, 4 groups of horizontal static load tests under different slopes and same soil properties were designed as indoor physical simulation. The test scheme is shown in Table 1.

The physical simulation was carried out in the threedimensional mechanical model system test bed, the dimension of which is $4 \mathrm{~m} \times 2 \mathrm{~m} \times 1.5 \mathrm{~m}$. The boundary effect considered in this test is 5-9 times the diameter of the pile [16], and the size of the three-dimensional model is $1.5 \mathrm{~m} \times 1.1 \mathrm{~m} \times 1.5 \mathrm{~m}$. Plane sketch of the model is shown in Figure 1, profile under $15^{\circ}$ slope is shown in Figure 2, and scene diagram of the indoor test is shown in Figure 3.

2.2. Design of Model. According to the similar-ratio principle and the size of the laboratory test bench, the geometric similarity ratio of the model test is determined to be 10 . The size and concrete grade of the prototype square pile are $1 \mathrm{~m} \times 1 \mathrm{~m} \times 10 \mathrm{~m}$ and C30, respectively. So the size and concrete grade of the model square pile are $0.1 \mathrm{~m} \times 0.1 \mathrm{~m} \times 1 \mathrm{~m}$ and $\mathrm{C} 30$, respectively, too. In order to conform to the similar conditions, 4 steel bars with $6 \mathrm{~mm}$ diameter are used as the main reinforcement of the model pile, and $2 \mathrm{~mm}$ fine wire is arranged as stirrups with equal spacing of $10 \mathrm{~cm}$.

The model soil was prepared based on the prototype soil according to the similarity ratio. Referring to the particle size distribution of the prototype soil, we replaced the particle of model soil according to the principle of equivalent substitution. The particles with a size of $>40 \mathrm{~mm}$ were replaced by those with a size of $5-40 \mathrm{~mm}$ and the particles with a size of $<5 \mathrm{~mm}$ were prepared according to the naturally graded curve. The physical and mechanical parameters of it are regulated to close to the undisturbed soil. In this test, the main materials of model soil are boulder and gravel, and fine-grained soil is cohesive soil. The physical and mechanical parameters of model soil are shown in Table 2. Model soil is shown in Figure 4.

2.3. Monitoring System. The main monitoring elements are the displacement dial indicator and Particle Image Velocimetry (PIV) System. The horizontal displacement of pile top is collected by two dial gauges, one of which is placed on the top of pile and the other is placed $10 \mathrm{~cm}$ below the top of pile. The vectorial displacement field of soil around the pile is collected by a high-speed camera installed above the soil
TABle 1: Test scheme.

\begin{tabular}{lccc}
\hline Number & $\begin{array}{c}\text { Types of } \\
\text { model soil }\end{array}$ & $\begin{array}{c}\text { The angle } \\
\text { of the slope }\end{array}$ & Pile \\
\hline 1 & & 0 & Concrete square pile \\
2 & Detritus & 15 & Section size: \\
3 & & 30 & $0.1 \mathrm{~m} \times 0.1 \mathrm{~m} \times 1 \mathrm{~m}$ \\
4 & & 45 & \\
\hline
\end{tabular}

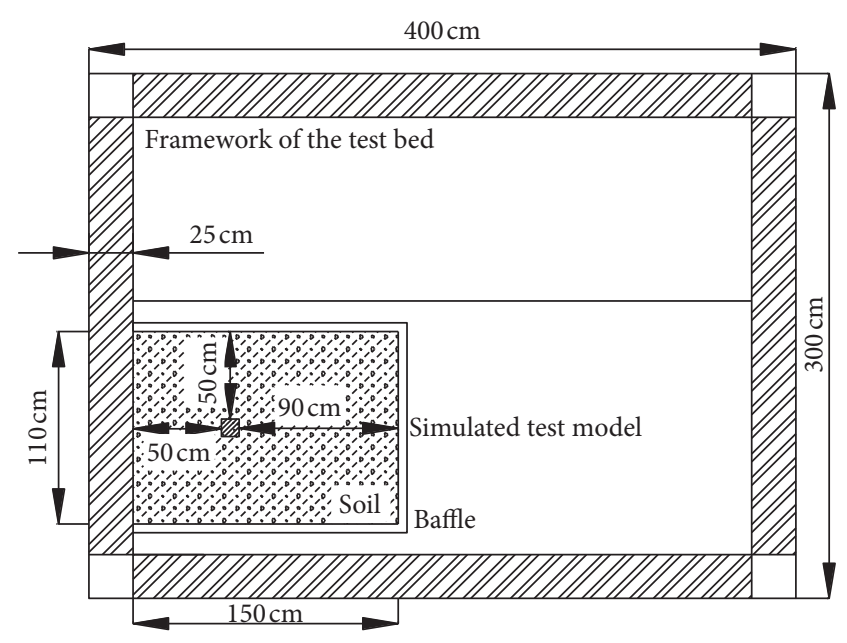

FIgURE 1: The plane chart of the simulation test.

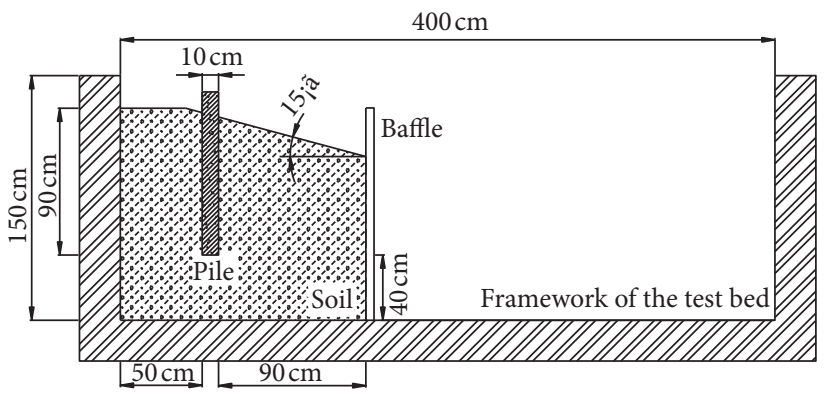

FIgURE 2: The profile chart under $15^{\circ}$ slope.

surface. The layout of the monitoring elements is shown in Figure 5.

In order to research the soil strain around the pile quantitatively, 13 gauge points were symmetrically arranged on both sides of the pile according to the diffusion angles (center, $0^{\circ}, 15^{\circ}, 30^{\circ}, 38^{\circ}, 45^{\circ}$, and $52^{\circ}$ ). These points will move with the variation of displacement of soil. Gauge points are arranged in three rows and the distance between every row and the pile is $0 \mathrm{~b}, 0.75 \mathrm{~b}$, and $1.5 \mathrm{~b}$, respectively. The overhead view of the gauge points is shown in Figure 6.

The $0 \mathrm{~b}$ row in front of the pile is shown in Figure 7 as an example.

The hydraulic servo system was used to load and unload step by step and the process of loading and observation is shown as follows: 


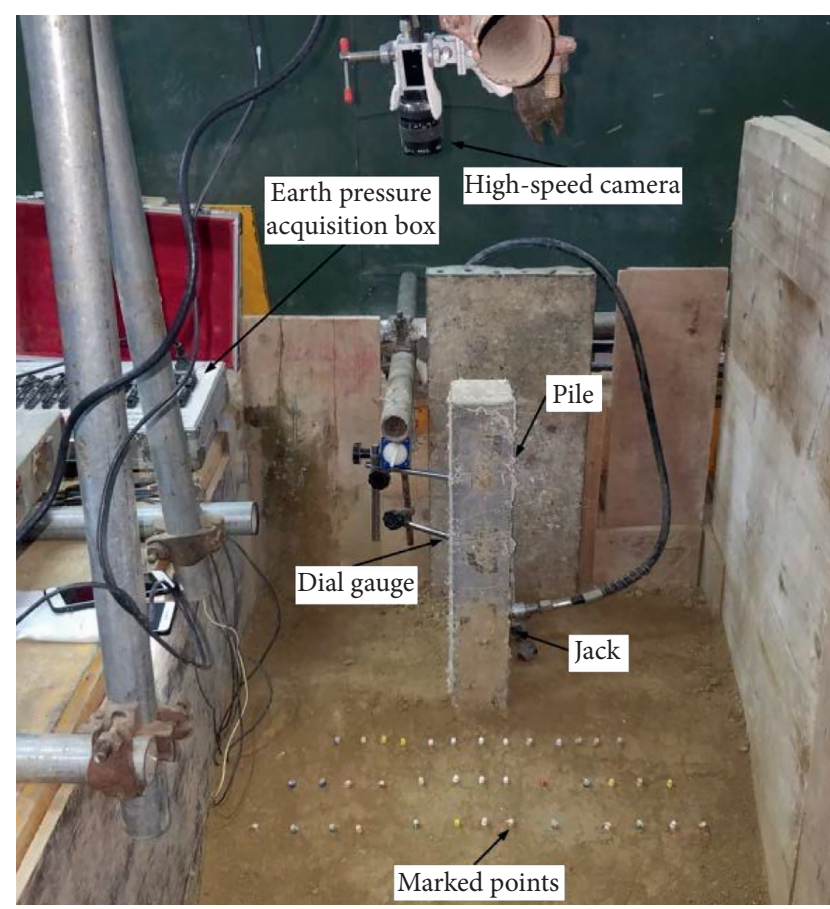

Figure 3: Scene diagram of model test.

TABle 2: Parameters of model soil.

\begin{tabular}{lcc}
\hline Soil & \multicolumn{2}{c}{ Physical-mechanical parameters } \\
\hline & $\gamma\left(\mathrm{kg} / \mathrm{m}^{3}\right)$ & 22.0 \\
& $C(\mathrm{kPa})$ & $7-10$ \\
Detritus & $\varphi\left({ }^{\circ}\right)$ & 45 \\
& $\mathrm{Cu}$ & 13.8 \\
& $\mathrm{Cc}$ & 1.53 \\
\hline
\end{tabular}

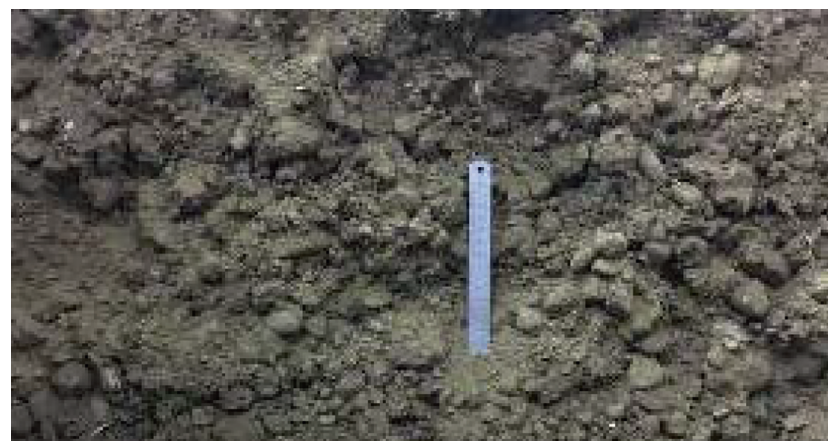

Figure 4: Model soil.

(1) Grading of loading: in order to facilitate the comparison of the test results, the increment of loading per grade is about $0.3 \mathrm{kN}$.

(2) Process of observation: the performance of each monitoring element is confirmed well before loading. The horizontal displacement of pile top is read and measured in 5 minutes after load at each grade is applied.

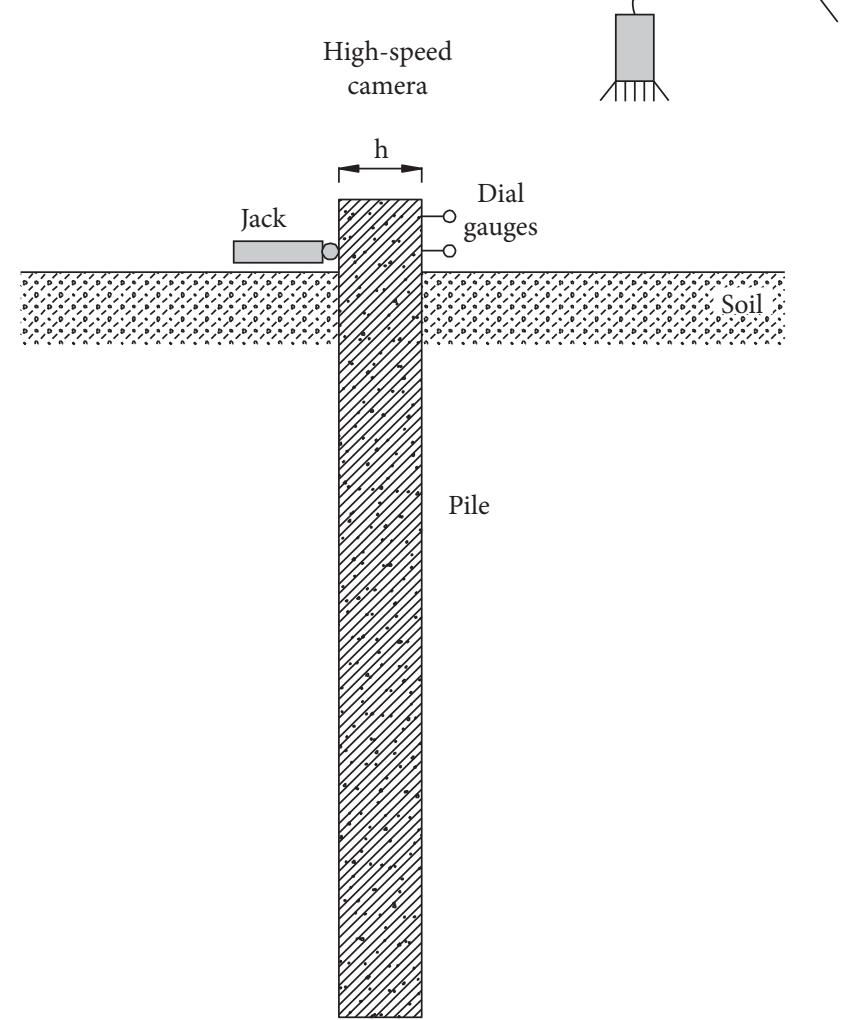

FIgURE 5: Layout of measuring elements.

Conditions for termination are as follows: (1) the pile being damaged, (2) soil surface crack or uplift obviously in front of pile, and (3) the displacement of pile top exceeding $30 \mathrm{~mm}$

2.4. Relation between Displacement and Load of Pile Top. The displacement-load curves of pile top under 4 slopes are drawn in Figure 8.

Displacement of pile top increases with the growth of load nonlinearly under different slopes and the growth of slope under the same load, and the required load for the plastic failure of the soil decreases with the increase of slope. In other words, the bigger the slope is, the weaker the resistance of the soil around the pile to the horizontal load on the pile is and the easier the pile is to lose stability.

Horizontal load-displacement gradient curves of pile top are drawn according to the load-displacement of pile top curves, as shown in Figure 9.

For the load-displacement gradient curve under $0^{\circ}$ slope, the first obvious inflection point appeared at $5.11 \mathrm{kN}$. In other words, the critical load under $0^{\circ}$ slope is $5.11 \mathrm{kN}$. The second obvious inflection point appeared at $7.12 \mathrm{kN}$. In other words, the ultimate load under $0^{\circ}$ slope is $7.12 \mathrm{kN}$. Similarly, the critical load and the ultimate load under $15^{\circ}$ slope are $4.09 \mathrm{kN}$ and $5.91 \mathrm{kN}$, respectively. The critical load and the ultimate load under $30^{\circ}$ slope are $2.10 \mathrm{kN}$ and $4.71 \mathrm{kN}$, respectively. The critical load and the ultimate load under $45^{\circ}$ slope are $1.97 \mathrm{kN}$ and $3.25 \mathrm{kN}$, respectively. 


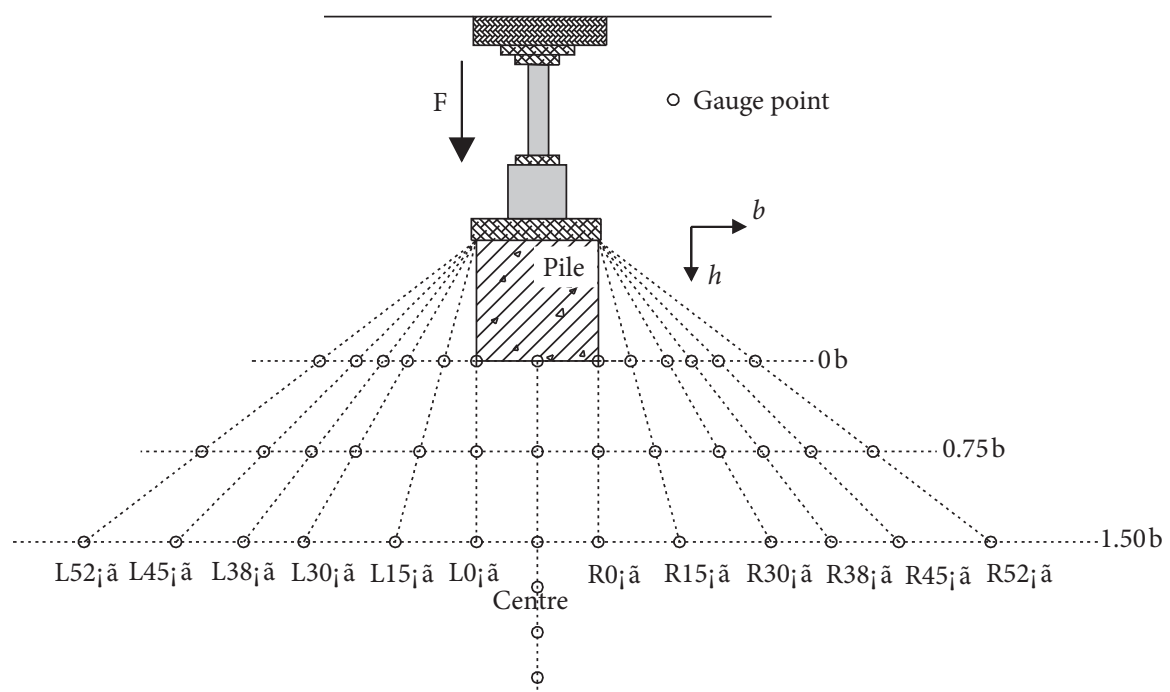

FIgURE 6: Overhead view of the layout of gauge points.

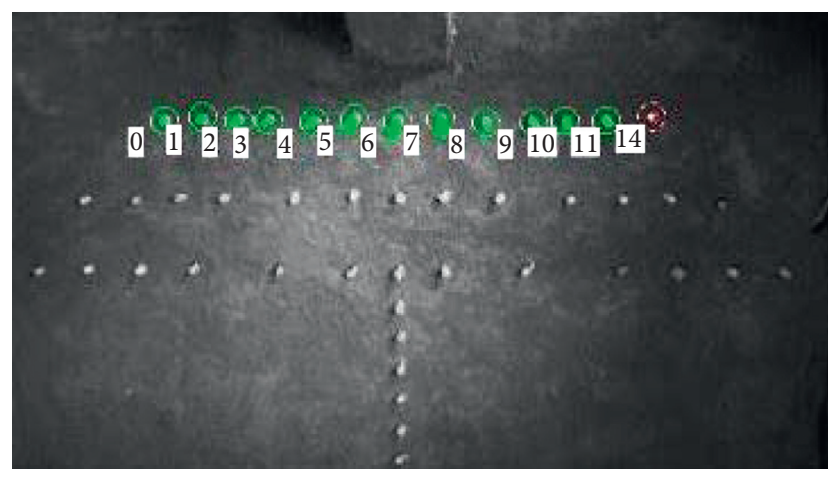

Figure 7: Example of gauge points.

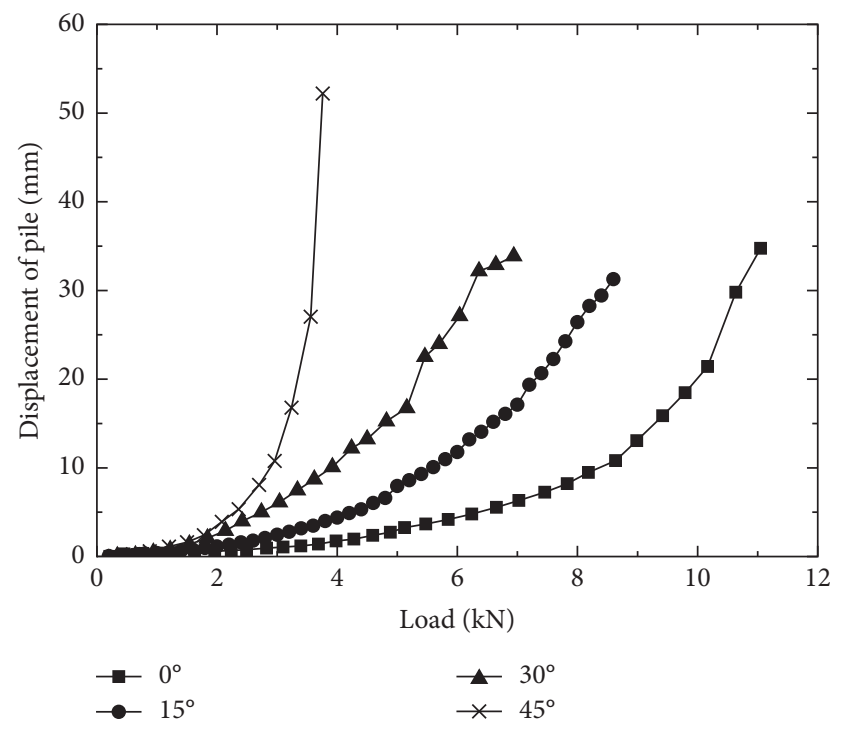

Figure 8: Curves of pile displacement load under 4 slopes.

2.5. Vectorial Displacement Field of Soil. Particle Image Velocimetry (PIV) system is mainly composed of a highspeed camera and a computer. Its basic principle is as follows: PIV divides the collected image into many grid windows. Then, the computer selects the window matching between the two frames according to the cross-correlation algorithm to match the displacement and direction of the center point of the window, representing the average displacement and direction of the particles in the window [17]. The PIV used in this test is shown in Figure 10.

High-speed photos of soil around piles with 4 slopes under different loads are collected by the PIV system and the vectorial displacement field of soil is analyzed by the PIV process Flow Field processing system. Vectorial displacement field of soil with $15^{\circ}$ is shown in Figure 11 as an example.

Under the slopes at $0^{\circ}, 15^{\circ}, 30^{\circ}$, and $45^{\circ}$, the displacement vectors paralleling the load appeared on the soil in front of the pile firstly when the load was small and appeared along the broadside of the pile at a certain angle with the load subsequently. With the load increases, the displacement vectors in front and the side of piles will increase further. With the beginning of the plastic deformation of soil, the soil fissures began to appear in the soil around the pile, and the displacement vectors of each area increase further along the original direction. When the soil is completely destroyed, the displacement vectors will not change anymore. At this time, the displacement vectors diffuse and attenuate in an approximately annular shape around the front of the pile [18]. For example, the slope of $45^{\circ}$ is shown in Figure 12.

2.6. Effective Calculative Width. In China, the current calculative width of pile is mostly calculated according to the Technical Code for Building Pile Foundations (JGJ94-2008), as shown in Table 3.

Pile-soil interaction is a complex spatial problem. Because of the existence of skin friction along with the pile, more soils around the pile form a whole and exert resistance together to bear horizontal load. This leads to the fact that the width bearing the horizontal load is larger than the actual 


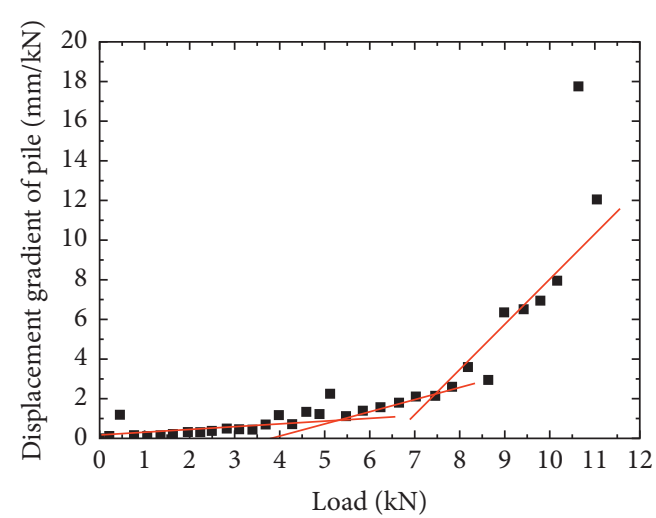

(a)

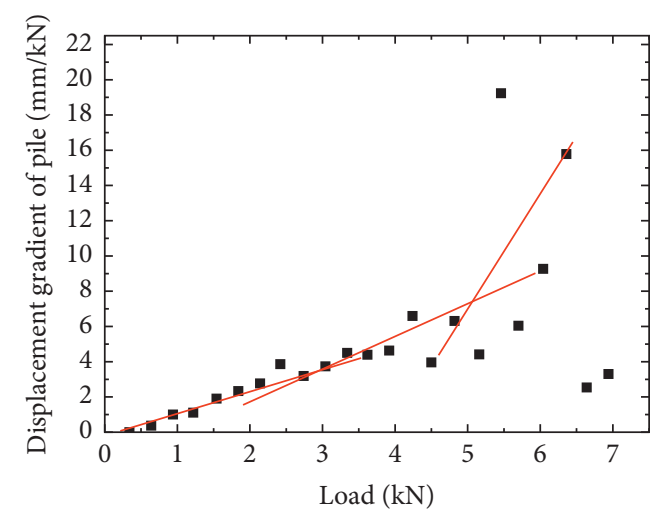

(c)

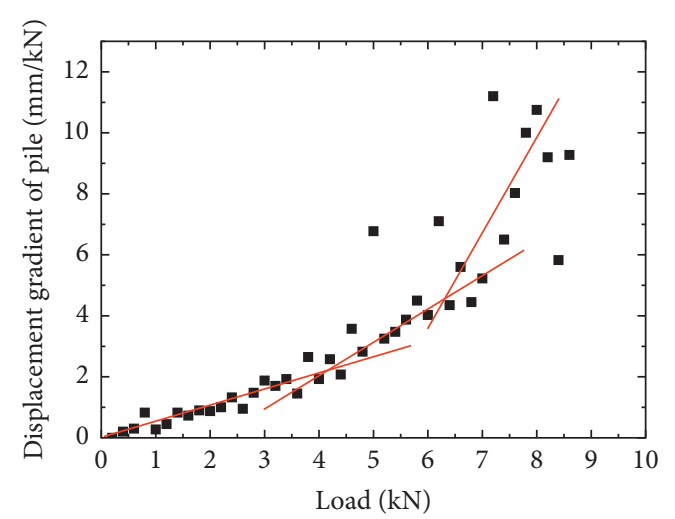

(b)

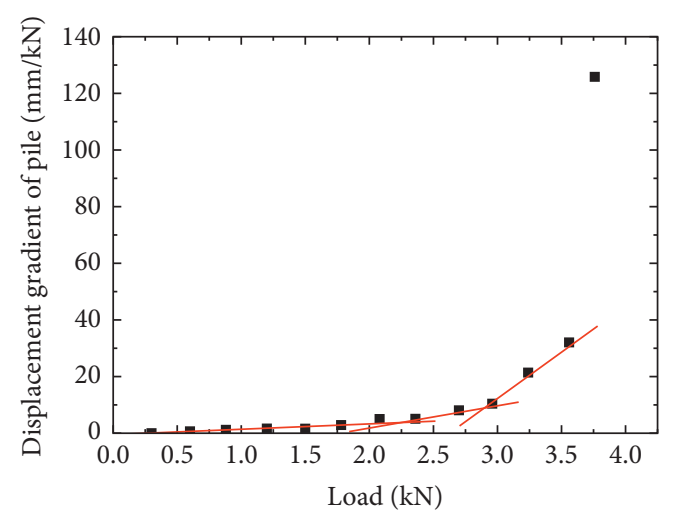

(d)

FIgURE 9: Horizontal load-displacement gradient curve of pile. (a) $0^{\circ}$ slope, (b) $0^{\circ}$ slope, (c) $0^{\circ}$ slope, and (d) $0^{\circ}$ slope.

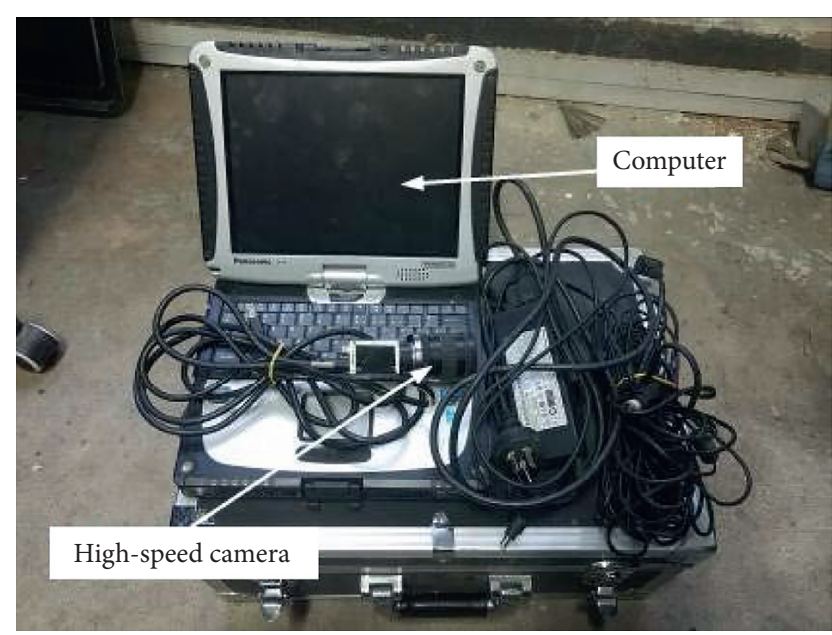

Figure 10: PIV device.

width of pile. This phenomenon is called Horizontal Diffusion Principle and is shown in Figure 13 [19].

In order to illustrate the effective calculating width, Horizontal Diffusion Principle of the single pile is simplified as Figure 14 based on the introduction of diffusion angle- $\phi$.

Under horizontal load $(F)$, the skin friction $(f)$ on both sides of pile drives more soil to participate in bearing horizontal load due to the interaction of forces. Therefore, the calculative width bearing the horizontal load of pile foundation is composed of two parts: (1) the actual width of the pile $b$ and (2) the width in which skin friction drives more soil to participate in bearing load- $2 \times h \operatorname{tg} \phi$.

For the convenience, to calculate, the effective calculative width of the pile is converted to the width in plane view. So the formula for effective calculative width proposed in this paper is shown as follows:

$$
B_{0}=k_{\phi} k(b+2 \mathrm{htg} \varphi)
$$

where $b$ is the pile width perpendicular to the direction of the force $(\mathrm{m}), h$ is the pile height $(\mathrm{m}), \phi$ is the horizontal diffusion angle $\left({ }^{\circ}\right), k_{\varphi}$ is the conversion coefficient of foundation shape (the value of round pile is 0.9 and the value of square pile is 1 ), and $k$ is interaction coefficient between piles. (When $L_{1} \geq 0.6 h_{1}, k=1.0$; when $L_{1}<0.6 h_{1}$, $k=b_{1}+\left(1-b_{1}\right) L_{1} / 0.6 l, L_{1}$ is the pile spacing paralleling to the direction of external force $(\mathrm{m}), h_{1}$ is the embedment depth of pile below ground $(\mathrm{m})$, and $b_{1}$ is the coefficient determined by the number $n_{1}$ of piles in a row parallel to the direction of external forces adopted by Table 4).

In order to quantify the horizontal diffusion angle and eliminate the errors caused by the position of camera, the displacement value of each row of central point on the same slope was set to be 1 , and other displacement values were nondimensionalized according to the same proportion. In this way, the displacement distribution curve 

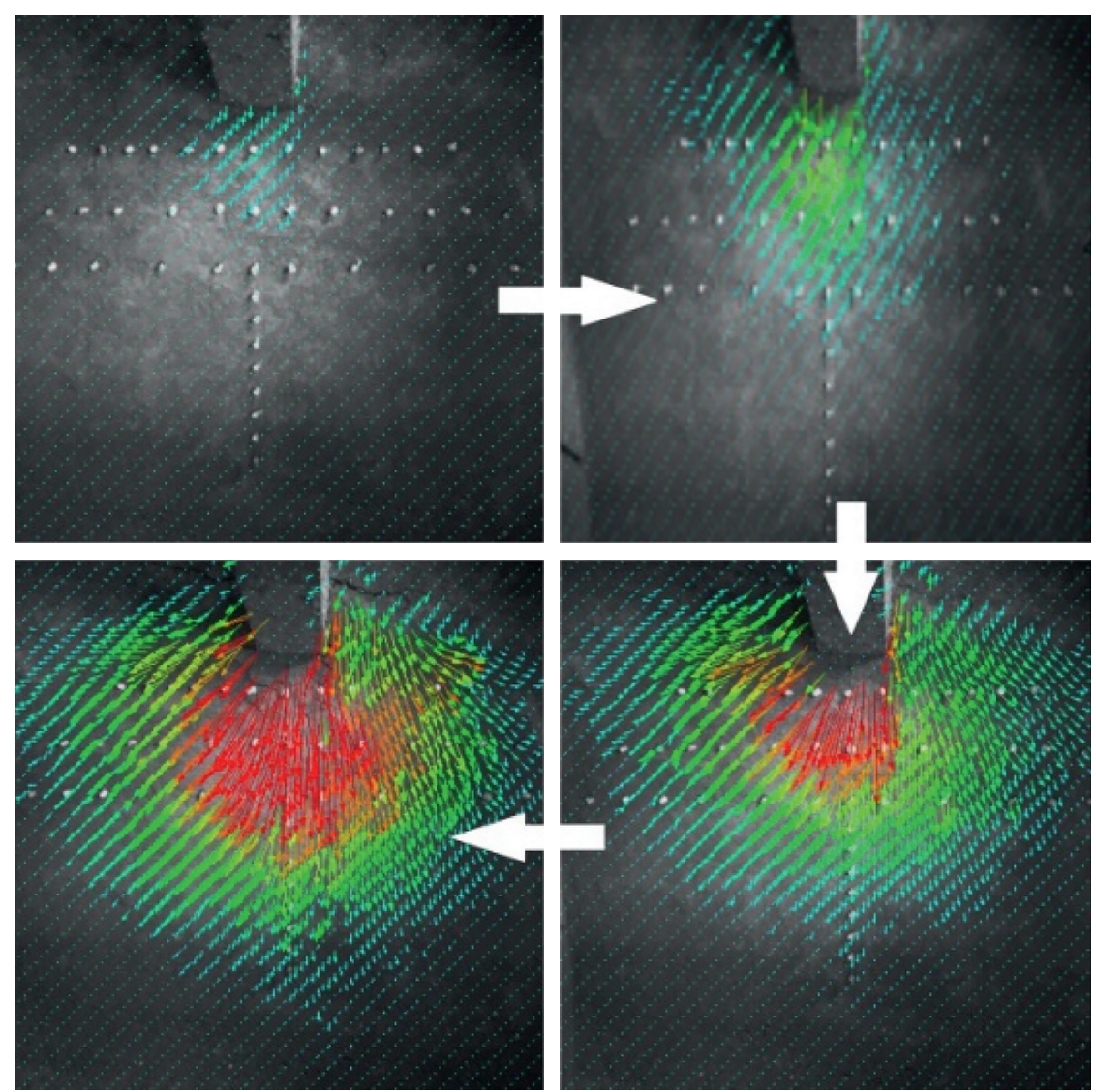

Figure 11: Vectorial displacement field under $45^{\circ}$ slope.

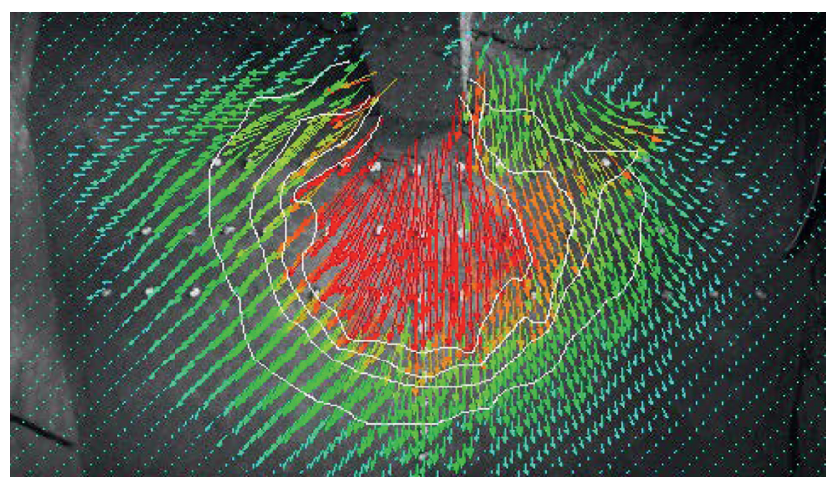

Figure 12: Displacement attenuation of soil around pile.

TABLE 3: The calculative width adopted in civil engineering.

\begin{tabular}{lcc}
\hline Pile diameter $d$ or side length $b(\mathrm{~m})$ & Calculative width of the circular piles & Calculative width of the square pile \\
\hline$>1$ & $0.9(d+1)$ & $b+1$ \\
$\leqq 1$ & $0.9(1.5 d+0.5)$ & $1.5 \mathrm{~b}+0.5$ \\
\hline
\end{tabular}

of gauge points of each row under 4 slopes is drawn as Figures 15-18:

On the same slope, the distribution curve of soil displacement under the same row is similar bearing the different loads. The relationship curve between the soil displacement and the layout angle of gauge points is like normal distribution and the central displacement is the largest. With the increase of distance for gauge points in the same row to pile, the displacement of soil decreases nonlinearly. In addition, under the same slope, the concentrative trend of the curve is the $0 \mathrm{~b}$ row $>0.75 \mathrm{~b}$ row $>1.50 \mathrm{~b}$ row. The reason for this phenomenon is that the farther away from the pile, the weaker the tendency of shear failure caused by soil movement driven by skin friction of pile. 


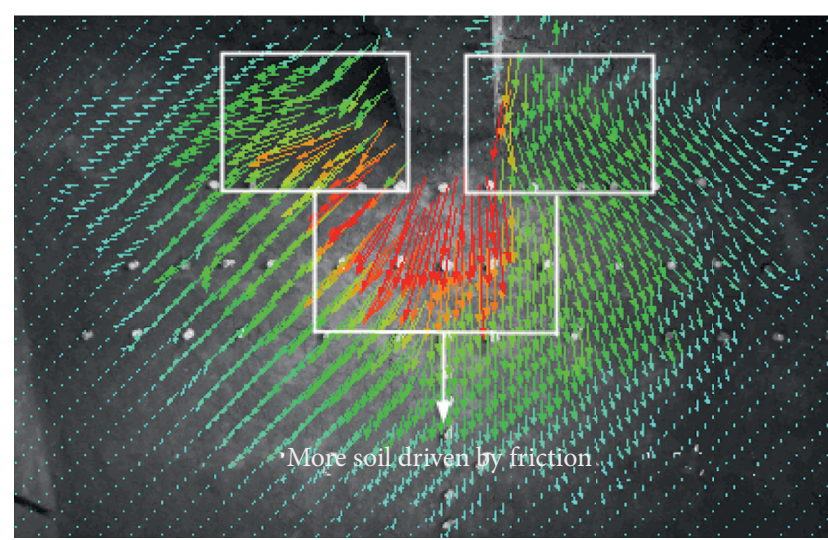

Figure 13: Horizontal Diffusion Principle.

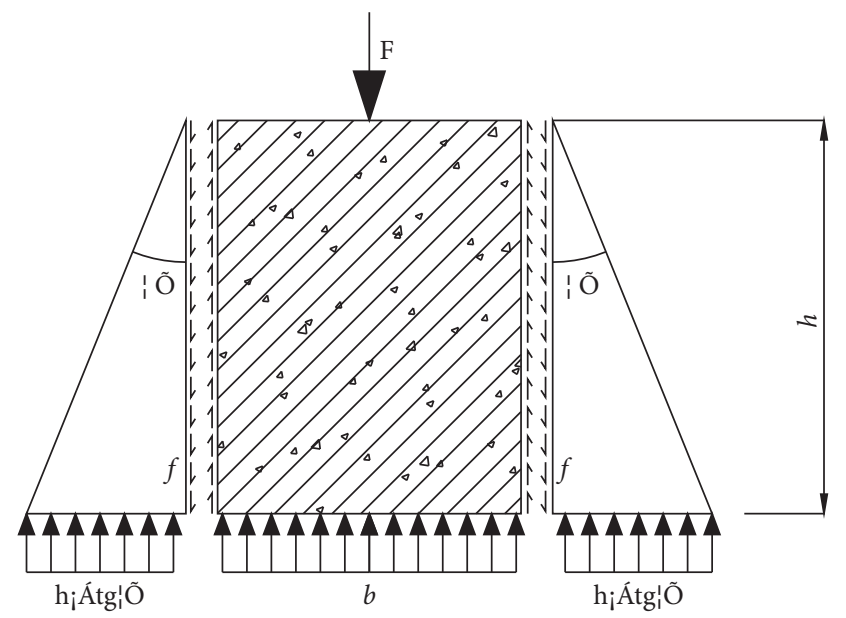

Figure 14: Sketch map of calculative width.

TABLE 4: The coefficient of $b_{1}$.

\begin{tabular}{lccc}
\hline$\left(n_{1}\right)$ & $\left(b_{1}\right)$ & $\left(n_{1}\right)$ & $\left(b_{1}\right)$ \\
\hline 1 & 1.0 & $\geq 3$ & 0.5 \\
2 & 0.6 & $\geq 4$ & 0.45 \\
\hline
\end{tabular}

In order to analyze the relationship between soil displacement and horizontal diffusion angle quantitatively, the distribution curves of soil displacement ratio by the position of gauge points were integrated based on the Interpolation Method. Then, the horizontal diffusion angle was calculated by integral value. Finally, effective calculative width was calculated by combining formula (1). The results are shown in Table 5.

\section{Numerical Simulation}

In order to supplement the laboratory model test, numerical simulations were carried out to calculate taking the full-scale test as prototypes. In this way, distribution of Earth pressure at $0.2 \mathrm{~m}$ below the horizontal surface of the soil was obtained and horizontal diffusion angle based on this Earth pressure was analyzed. Combining with formula (1), effective calculative width was calculated.
3.1. Establishment of Model. A Finite-Difference Method(FDM-) FLAC3D program was used to simulate the effect of slope on the pile foundation under different slopes. Taking a steep slope in Sima Village, Xuecheng Town, Lixian County, Sichuan Province, China, as the prototype, and a threedimensional numerical model was established. The numerical model takes into account the working conditions of $0^{\circ}, 15^{\circ}, 30^{\circ}$, and $45^{\circ}$ slope under the same soil and pile parameters. Tetrahedron was used to mesh in order to improve the running speed and reduce the boundary effect [16]. The dimension of the numerical model is $200 \mathrm{~m} \times 100 \mathrm{~m} \times 80 \mathrm{~m}$. According to the full-scale test, the size of the model pile is $1 \mathrm{~m} \times 1 \mathrm{~m} \times 10 \mathrm{~m}$ and the length of the pile body exposed is $1 \mathrm{~m}$.

The generalized numerical model for $45^{\circ}$ slope is shown in Figure 19.

3.2. Model Parameters. The parameters of numerical model include cohesion, internal friction angle, Poisson's ratio, shear modulus, and bulk modulus. The normal and shear stiffness of the pile-soil interface was set to be 10 times of the equivalent stiffness of the surrounding soil, and all the parameters are shown in Table 6.

3.3. Loading of the Model. $150 \mathrm{kN}$ is used as the increment to load step by step in the horizontal direction. When the maximum unbalanced force is unchanged, that is, when the corresponding entity test soil is in completely plastic destruction, the loading is stopped.

3.4. Result Analysis. The diffusion angle is obtained by analyzing the stress spread of the soil around the model piles in FLAC ${ }^{3 \mathrm{D}}$. The effective calculative width of different slopes obtained by combining formula (1) is shown in Table 7.

Tables 5 and 7 are used to plot the relationship between calculative width and slope angle, as shown in Figure 20.

The results of numerical and physical simulation show good synergy. Under the level ground, calculative width based on Horizontal Diffusion Principle is greater than that based on code but it decreases substantially linearly with the increase of slope angle. Calculative width decreases by about $0.33 \mathrm{~m}$ with the increase of slope by $15^{\circ}$ in this test. The decrease of calculative width means the scale of soil that resists horizontal load is reduced and slope has obvious weakening effects on this scale.

\section{Full-Scale Test}

4.1. Terrain Landform. The full-scale test is located on a high and steep slope on the left bank of Sima Village and its geographic coordinates are east longitude $103^{\circ} 12^{\prime} 36^{\prime \prime}$ and north latitude $31^{\circ} 36^{\prime} 36^{\prime \prime}$. The elevation of the slope is between $1700-1900 \mathrm{~m}$. Pile position of the site is shown in Figure 21.

4.2. Stratigraphic and Lithologic. The overlying layer is dominated by quaternary loose slope sediment $(\mathrm{Q} 4 \mathrm{col}+\mathrm{dl})$ with a thickness of $3-15 \mathrm{~m}$ and the thickness of the test pile is 


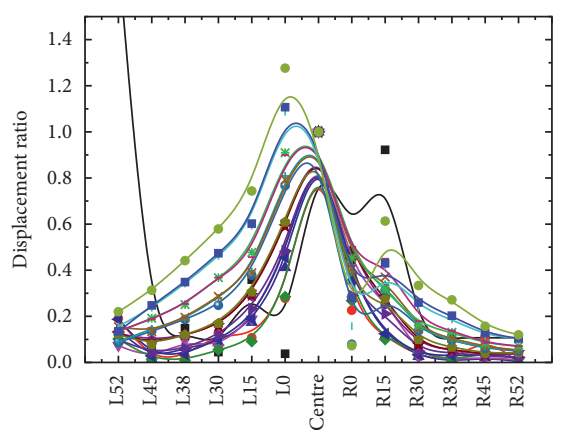

Marked point $\left({ }^{\circ}\right)$

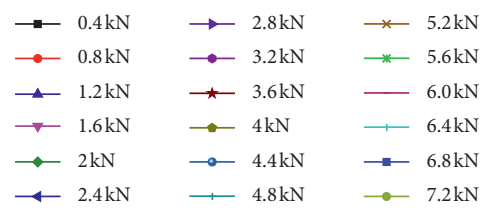

(a)

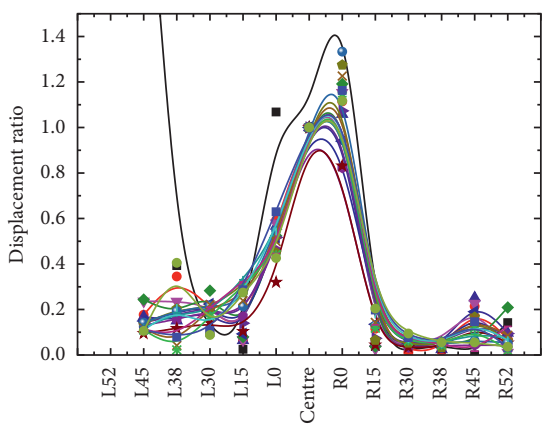

Marked point $\left(^{\circ}\right)$

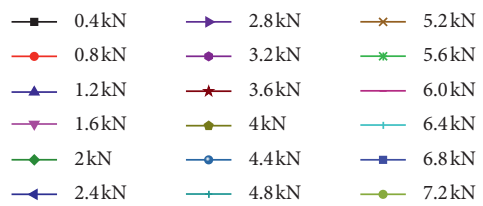

(b)

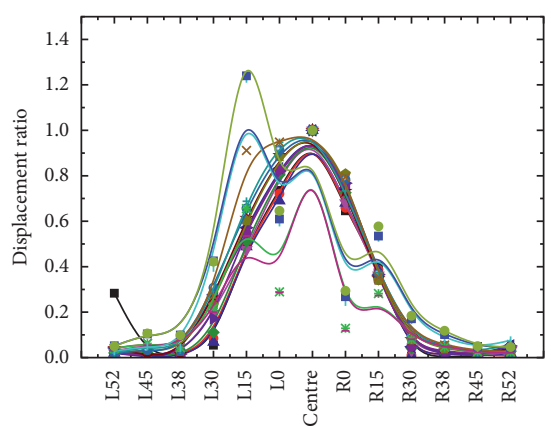

Marked point $\left({ }^{\circ}\right)$

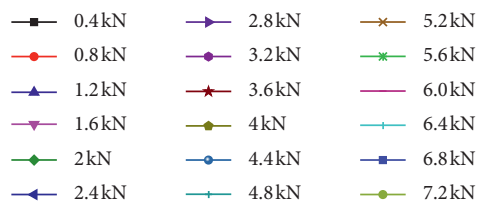

(c)

Figure 15: Distribution curve of soil displacement according to diffusion angle under different loads at $0^{\circ}$. (a) The $0 b$ row. (b) The $0.75 b$ row. (c) The $1.50 \mathrm{~b}$ row.

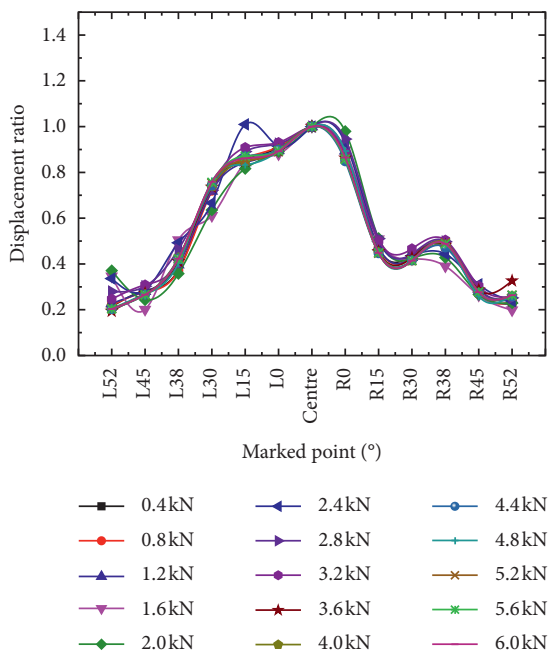

(a)

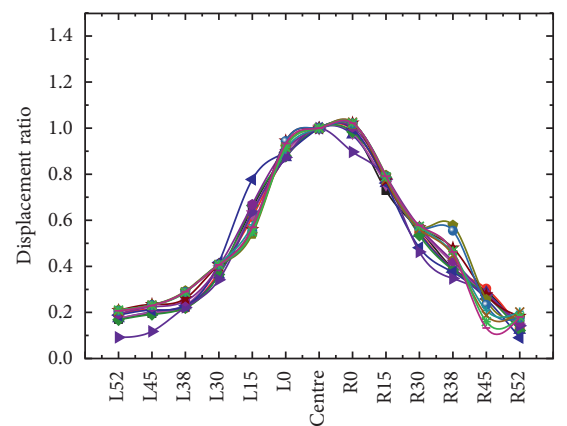

Marked point $\left(^{\circ}\right)$

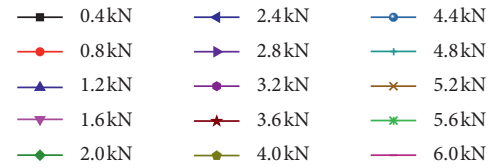

(b)

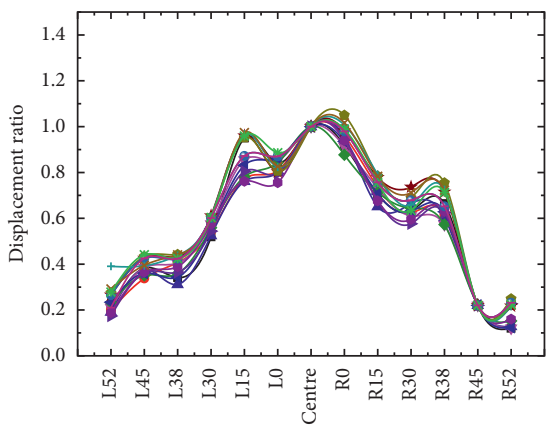

Marked point $\left(^{\circ}\right)$

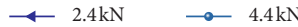

$\rightarrow-2.8 \mathrm{kN}$

$\rightarrow 3.2 \mathrm{kN}$

$\star 3.6 \mathrm{kN}$

$+4.8 \mathrm{kN}$

$\rightarrow 1.6 \mathrm{kN}$

$\rightarrow 2.0 \mathrm{kN}$

$\rightarrow 4.0 \mathrm{kN}$

* $5.6 \mathrm{kN}$

(c)

Figure 16: Distribution curve of soil displacement according to diffusion angle under different loads at $15^{\circ}$. (a) The $0 b$ row. (b) The $0.75 b$ row. (c) The $1.50 \mathrm{~b}$ row.

more than $10 \mathrm{~m}$ which is more than the length of the pile. This layer is gravel soil, which is slightly medium in density, the particle size is generally $3-8 \mathrm{~cm}$, and the maximum particle size can reach $50 \mathrm{~cm}$ filling a small amount of clay and gravel between the stones. For example, please refer to $30^{\circ}$ slope, as shown in Figure 22.

A series of laboratory physical and mechanical tests were carried out on undisturbed soil. The test results are shown in Table 8.

4.3. Data Collection and Loading. A total of three dial indicators were installed on the left and right sides and the center of the pile top to measure the displacement of the pile top, and another dial indicator was installed about $40 \mathrm{~cm}$ below the pile top dial indicator to measure the displacement of the mud surface of the pile. Two inclinometers were symmetrically tied to the steel cage on the neutral plane of the pile to measure the displacement after each increase of load. The lateral load adopts a one-way slow-speed maintenance method, and each grade of loading is $1 / 10-1 / 15$ of the estimated ultimate load. The standard for pile stability is that the displacement of the pile top does not exceed $0.1 \mathrm{~mm}$ within each hour. After loading, take the reading of the dial indicators of pile top every $5,10,15$, and 30 minutes.

\section{5. $m$-Value}

Based on $m$-method of pile, calculative width based on Horizontal Diffusion Angle and that based on Technical 


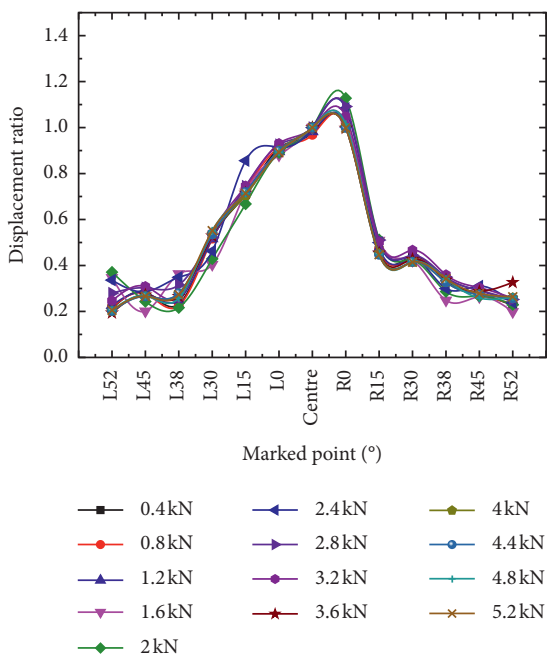

(a)

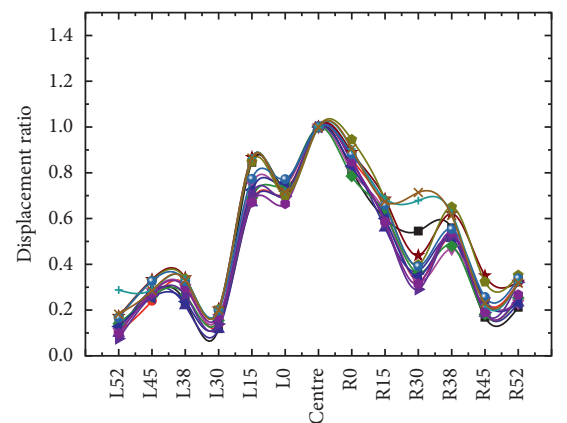

Marked point $\left(^{\circ}\right)$

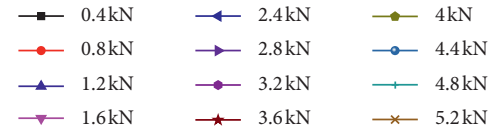

(b)

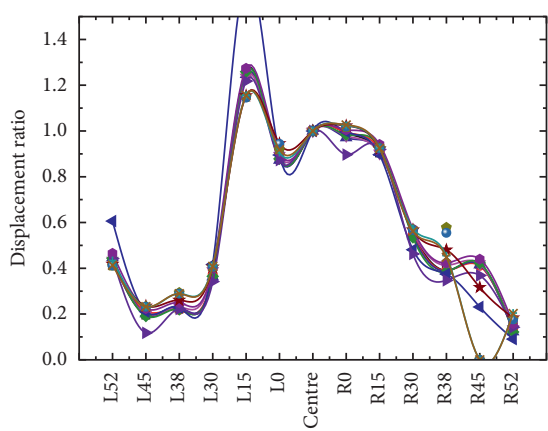

Marked point $\left({ }^{\circ}\right)$

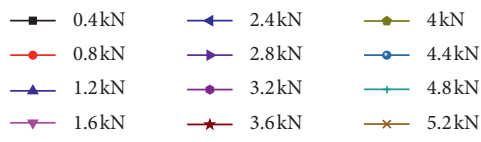

(c)

Figure 17: Distribution curve of soil displacement according to diffusion angle under different loads at $30^{\circ}$. (a) The $0 b$ row. (b) The $0.75 b$ row. (c) The $1.50 b$ row.

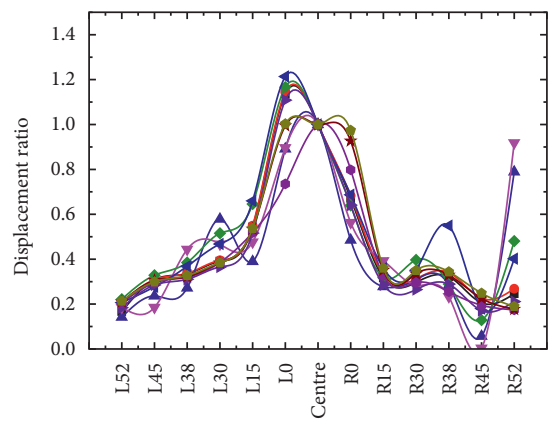

Marked point $\left(^{\circ}\right)$

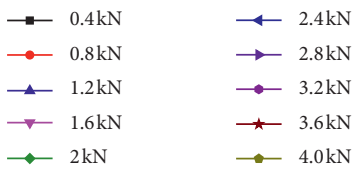

(a)

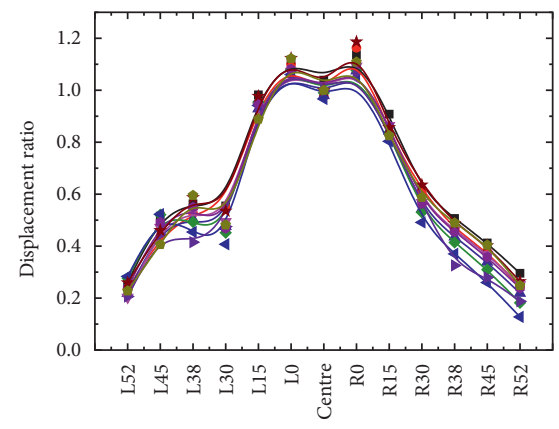

Marked point $\left(^{\circ}\right.$

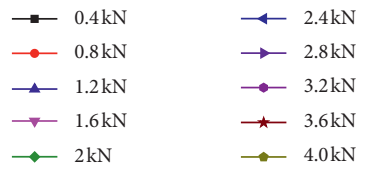

(b)

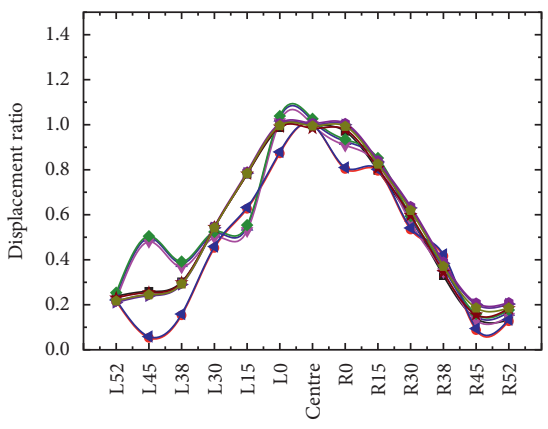

Marked point $\left(^{\circ}\right)$

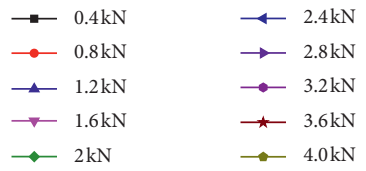

(c)

Figure 18: Distribution curve of soil displacement according to diffusion angle under different loads at $45^{\circ}$. (a) The $0 b$ row. (b) The $0.75 b$ row. (c) The $1.50 \mathrm{~b}$ row.

Code for Building Pile Foundations were compared to research the influence of slope on the horizontal bearing capacity taking the ratio coefficient $m$-value of horizontal resistance coefficient of pile foundation as an example. We have the calculation formula of $m$-value in Appendix E of Technical Code for Building Pile Foundations (JGJ94-2008) in China:

$$
m=\frac{\left(\left(H_{\mathrm{cr}} / X_{\mathrm{cr}}\right) v_{x}\right)^{5 / 3}}{b_{0}(\mathrm{EI})^{2 / 3}}
$$

where $H_{\mathrm{cr}}$ is the critical load of single pile $(\mathrm{kN}), X_{\mathrm{cr}}$ is the displacement corresponding to the critical load $(\mathrm{m}), v_{x}$ is the displacement coefficient of pile top which is determined by code, $b_{0}$ is the calculative width of pile $(\mathrm{m})$, and $\mathrm{EI}$ is the flexural rigidity of pile $\left(\mathrm{kN} \cdot \mathrm{m}^{2}\right)$.

5.1. m-Value Based on Horizontal Diffusion Principle. Calculative width- $b_{0}$ of formula (2) was substituted by effective calculative width- $b_{h}$ obtained from this test; $m$-values of 4 slopes were calculated as shown in Table 9.

5.2. $m$-Value Based on Code. Pile spacing of full-scale test is more than $6 \mathrm{~m}$, so the pile group effect can be neglected. 4 groups of full-scale tests' data were selected in order to obtain the horizontal bearing characteristics of pile under different slopes and the corresponding $m$-value. Calculative 
TABLE 5: Calculative width based on soil displacement.

\begin{tabular}{lcc}
\hline Slope $(\theta)$ & Diffusion angle- $\phi\left(^{\circ}\right)$ & Effective calculative width- $\left(b_{h}(\mathrm{~m})\right)$ \\
\hline 0 & 48.13 & $b+2 \mathrm{htg} 48.13^{\circ}$ \\
15 & 37.86 & $b+2 \mathrm{htg} 37.86^{\circ}$ \\
30 & 29.65 & $b+2 \mathrm{htg} 29.65^{\circ}$ \\
45 & 18.74 & $b+2 \mathrm{htg} 18.74^{\circ}$ \\
\hline
\end{tabular}

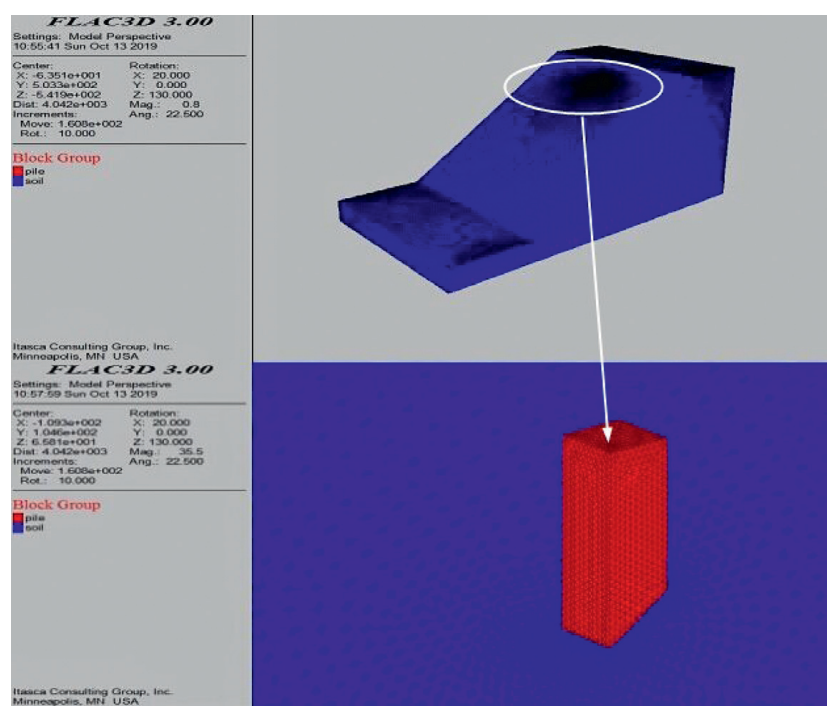

FIGURE 19: Generalization numerical model at $45^{\circ}$.

TABle 6: Material calculation parameters of the numerical model.

\begin{tabular}{lccccc}
\hline Model material & $\rho /\left(\mathrm{g} / \mathrm{cm}^{3}\right)$ & $(\mathrm{C} / \mathrm{kPa})$ & $\phi /\left(^{\circ}\right)$ & Bulk modulus $(K / \mathrm{MPa})$ & Shear modulus \\
\hline Pile & 2.5 & 1000 & 42 & 4825 & 5185 \\
Detritus & 2.2 & 10 & 45.62 & 150 & 100 \\
\hline
\end{tabular}

TABLe 7: Calculative width based on numerical simulation.

\begin{tabular}{lcr}
\hline Slope $\theta\left(^{\circ}\right)$ & Diffusion angle- $\phi\left(^{\circ}\right)$ & Calculative width $\left(b_{h}(\mathrm{~m})\right)$ \\
\hline 0 & 46.54 & $b+2 \mathrm{htg} 46.54^{\circ}$ \\
15 & 34.92 & $b+2 \mathrm{htg} 34.92^{\circ}$ \\
30 & 28.15 & $b+2 \mathrm{htg} 28.15^{\circ}$ \\
45 & 18.32 & $b+2 \mathrm{htg} 18.32^{\circ}$ \\
\hline
\end{tabular}

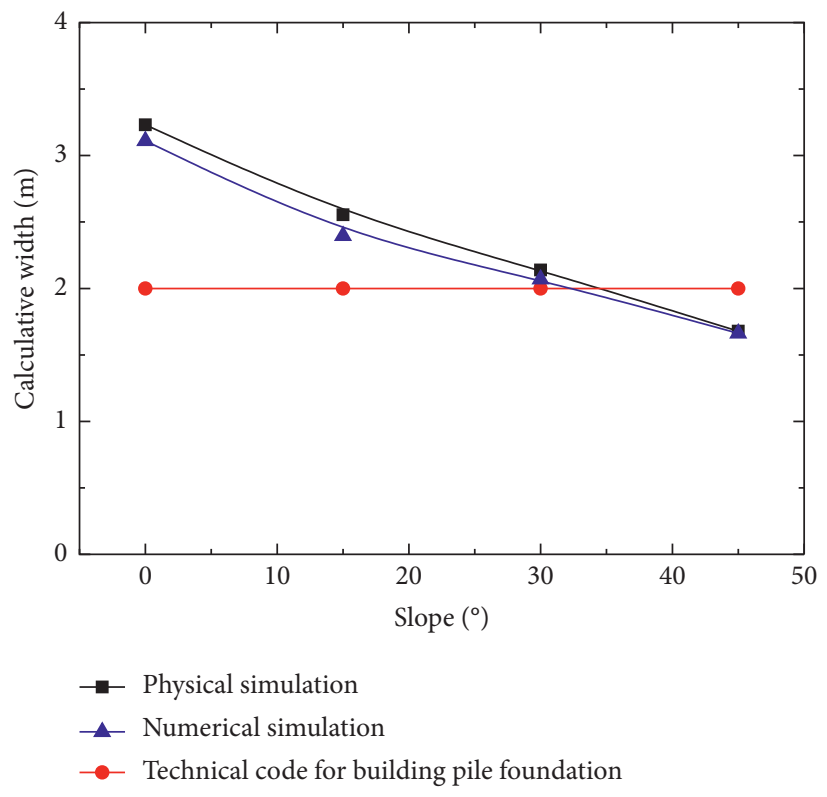

Figure 20: Curve of the calculative width with the slope. 

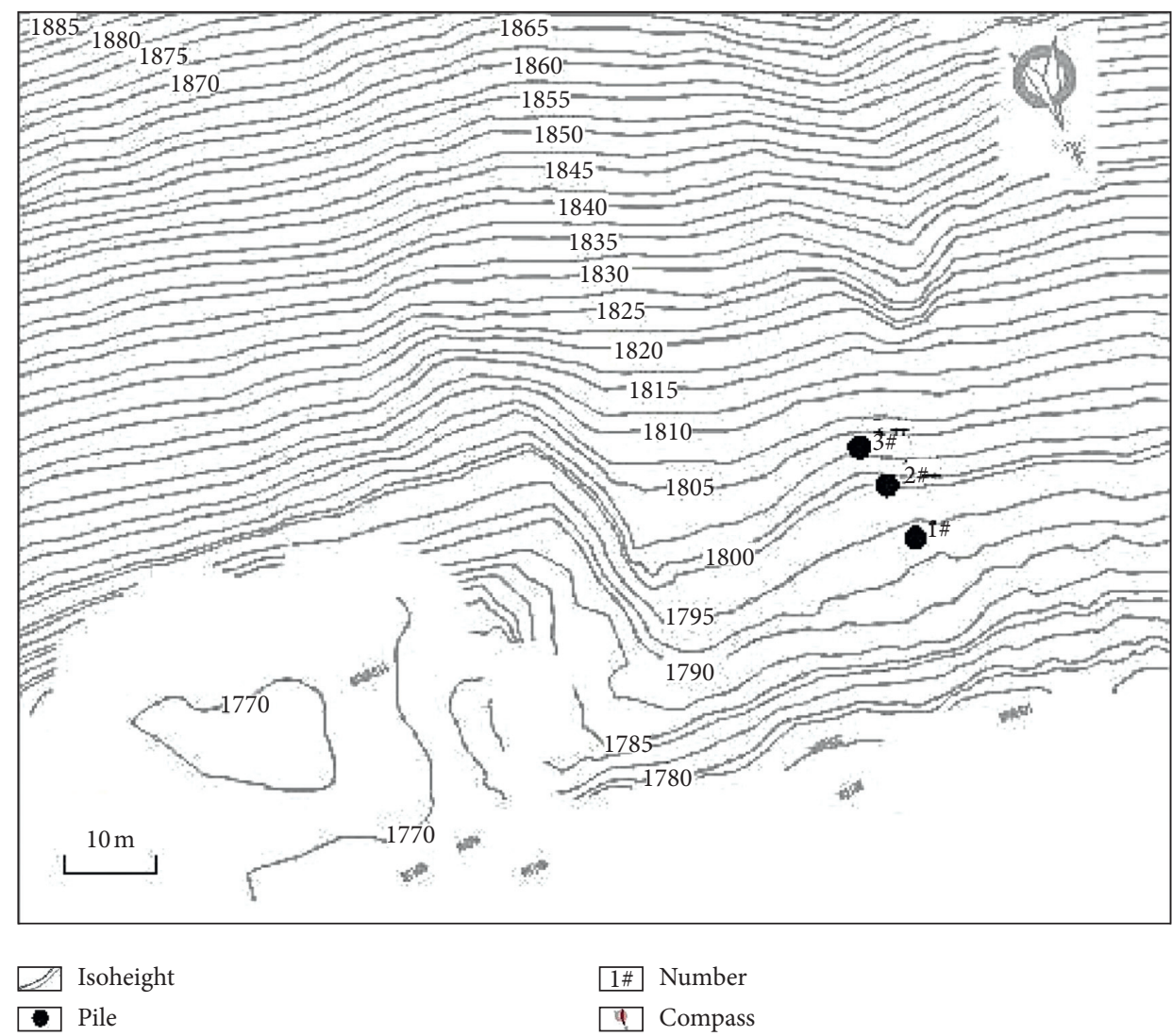

Figure 21: Layout of the pile in the full-scale test.

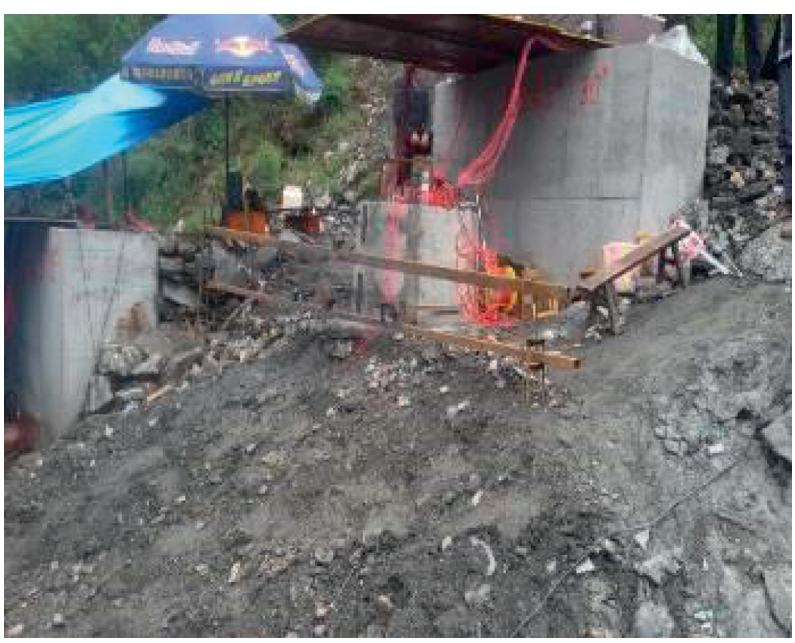

Figure 22: Field test under $30^{\circ}$.

width- $b_{0}$ of formula (2) was replaced by the recommended value of code for Technical Code for Building Pile Foundation (JGJ94-2008) in China. The general situation of pile foundation and the corresponding $m$-value are shown in Table 10 .

The synergy of $m$-value between model test and full-scale test under different slopes had been verified already [20]. This paper compared the $m$-values based on Horizontal Diffusion Principle and code as shown in Figure 23. $m$-value can reflect the horizontal bearing capacity of pile foundation, and it decreases nonlinearly with the increase of the slopes, and the relationship curve is concave upwards. However, $m$-values based on Horizontal Diffusion Principle are larger than those based on Technical Code for Building Pile Foundation (JGJ94-2008) in China, and the average difference is about $75 \mathrm{MN} / \mathrm{m}^{4}$ under the same slope. This is because the effective calculative width based on Horizontal Diffusion Principle is less than that based on Technical Code for Building 
TABLE 8: The mechanical parameters of undisturbed soil.

\begin{tabular}{lcc}
\hline Weight & $Y\left(\mathrm{kN} / \mathrm{m}^{3}\right)$ & 22 \\
Coefficients of uniformity & $\mathrm{Cu}$ & 22.7 \\
Curvature coefficient & $\mathrm{Cc}$ & 1.1 \\
Cohesion & $c(\mathrm{kPa})$ & 10 \\
Internal friction angle & $\varphi\left({ }^{\circ}\right)$ & 45.57 \\
Water content & $\omega(\%)$ & 6.3 \\
Optimum water content & $\omega(\%)$ & 6.6 \\
\hline
\end{tabular}

TABLE 9: $m$-value based on effective calculative width.

\begin{tabular}{lccc}
\hline $\begin{array}{l}\text { Slope } \\
\left({ }^{\circ}\right)\end{array}$ & $\begin{array}{c}\text { Critical load } \\
(\mathrm{kN})\end{array}$ & $\begin{array}{c}\text { Horizontal displacement } \\
(\mathrm{mm})\end{array}$ & $\begin{array}{c}m \text {-value } \\
\left(\mathrm{MN} / \mathrm{m}^{4}\right)\end{array}$ \\
\hline 0 & 5.11 & 3.27 & 220.69 \\
15 & 4.09 & 4.39 & 108.76 \\
30 & 2.10 & 2.87 & 92.19 \\
45 & 1.97 & 3.23 & 83.07 \\
\hline
\end{tabular}

TABLe 10: $m$-value based on calculative width recommended by code.

\begin{tabular}{lcccc}
\hline Stake number & $1 \#$ & $3 \#$ & $6 \#$ & $8 \#$ \\
\hline Slope $\left({ }^{\circ}\right)$ & 0 & 15 & 30 & 45 \\
Pile length $(\mathrm{m})$ & 10.5 & 10.2 & 10.5 & 10.5 \\
Embedment depth $(\mathrm{m})$ & 9.85 & 9.67 & 9.82 & 9.92 \\
Density $\left(\mathrm{g} / \mathrm{cm}^{3}\right)$ & 2.5 & 2.5 & 2.5 & 2.5 \\
$m$-value $\left(\mathrm{MN} / \mathrm{m}^{4}\right)$ & 110.01 & 42.67 & 30.35 & 21.47 \\
\hline
\end{tabular}

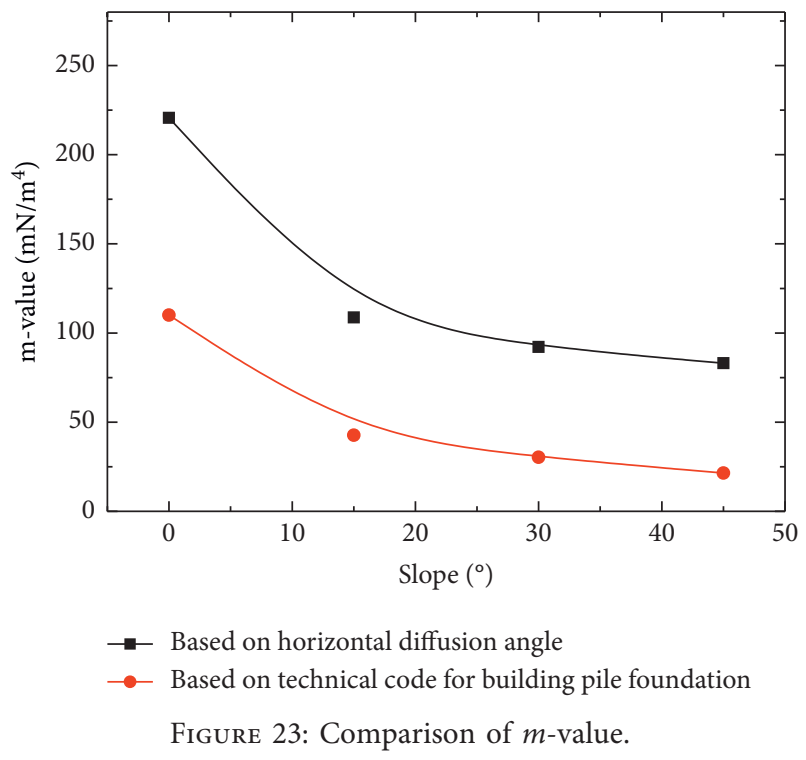

Pile Foundation (JGJ94-2008) in China, and the reduction effect of slope on the effective calculative width is not considered in the code.

\section{Conclusion}

(1) The vectorial displacement field of soil around the pile bearing horizontal load has a similar changing rule under different slopes and the change of it shows the annular stress diffusion characteristics; that is, the displacement vectors of soil around piles diffuse and attenuate in an approximate annular form from the center of the pile to the surroundings.

(2) The horizontal diffusion angle of pile foundation decreases approximately linearly with the increase of slope. In this test, the horizontal diffusion angle decreases by about $10^{\circ}$ with the increase of slope by $15^{\circ}$.

(3) The effective calculative width based on the Horizontal Diffusion Principle is less than the recommended width of the Technical Code for Building Pile Foundations in China under level ground, and it decreases by about $3.3 \mathrm{~m}$ with the increase of slope by every $15^{\circ}$.

$m$-value based on Horizontal Diffusion Principle decreases nonlinearly with the increase of slope and it is greater than that based on Technical Code for Building Pile Foundations in China. The average difference between two $m$-values is about $75 \mathrm{MN} / \mathrm{m}^{4}$. In the design of slope engineering, such as $m$-value, the reduction effect of slope on effective calculative width should be considered.

\section{Data Availability}

The data used to support the findings of this study are available from the corresponding author upon request.

\section{Conflicts of Interest}

The authors declare that there are no conflicts of interest regarding the publication of this paper.

\section{Acknowledgments}

This work was supported by the National Natural Science Foundation of China "Formation and Evolution Mechanism of a Kind of Deep Unloading with Asymmetric Development" (no. 41272333) and State Plan for Development of Basic Research in Key Areas "Disturbance Mechanism of Rock Mass Excavation of Valley Slope in High Stress Area" (no. 2011CB013501).

\section{References}

[1] C. Y. Lee, T. S. Hull, and H. G. Poulos, "Simplified pile-slope stability analysis," Computers and Geotechnics, vol. 17, no. 1, pp. 1-16, 1995.

[2] Z. Muszyński and J. Rybak, "Horizontal displacement control in course of lateral loading of a pile in a slope," IOP Conference Series: Materials Science and Engineering, vol. 245, no. 1, Article ID 32002, 2017.

[3] R. K. Rowe, "Pile foundation analysis and design: book review," Canadian Geotechnical Journal, vol. 18, no. 3, pp. 472-473, 1981.

[4] Y. K. Chow, "Axial and lateral response of pile groups embedded in nonhomogeneous soils," International Journal for Numerical and Analytical Methods in Geomechanics, vol. 11, no. 6, pp. 621-638, 1987. 
[5] J. Won, K. You, S. Jeong, and S. Kim, "Coupled effects in stability analysis of pile-slope systems," Computers and Geotechnics, vol. 32, no. 4, pp. 304-315, 2005.

[6] D. J. Kim and R. H. G. Parry, "Experimental determined distribution of stress around a horizontally loaded model pile in dense sand," International Journal of Rock Mechanics and Mining Sciences and Geomechanics Abstracts, vol. 23, no. 3, pp. 578-582, 1986.

[7] S. M. A. Zomorodian and M. Dehghan, "Lateral resistance of single pile located near carpet shred reinforced slope," American Society of Civil Engineers, vol. 8, no. 407, pp. 141149, 2011.

[8] R. Lang, S. Yan, L. Sun et al., "Analysis of stress diffusion angle method for PTC pile composite foundation," European Journal of Environmental \& Civil Engineering, vol. 22, no. 1, pp. s434-s448, 2017.

[9] P. F. Ruesta and F. C. Townsend, "Evaluation of laterally loaded pile group at roosevelt bridge," Journal of Geotechnical and Geoenvironmental Engineering, vol. 123, no. 12, pp. 1153-1161, 1997.

[10] B.-X. Yuan, W.-W. Chen, T. Jiang, Y.-X. Wang, and K.-P. Chen, "Stereo particle image velocimetry measurement of 3D soil deformation around laterally loaded pile in sand," Journal Of Central South University, vol. 20, no. 3, pp. 791798, 2013.

[11] S. Aoyama, W. Mao, S. Goto, and I. Towhata, "Application of advanced procedures to model tests on the subsoil behavior under vertical loading of group pile in sand," Indian Geotechnical Journal, vol. 46, no. 1, pp. 64-76, 2016.

[12] W. K. Towhata, Z. G. Zhou, and L. Y. Zhou, "Analysis of $m$ value for lateral loaded pile under large deflection," Rock and Soil Mechanics, vol. 29, no. 1, pp. 192-196, 2008.

[13] M. Huang, F. Liang, and J. Jiang, "A simplified nonlinear analysis method for piled raft foundation in layered soils under vertical loading," Computers and Geotechnics, vol. 38, no. 7, pp. 875-882, 2011.

[14] T. Juirnarongrit and S. A. Ashford, "Soil-pile response to blast-induced lateral spreading. II: analysis and assessment of the p-y method," Journal of Geotechnical and Geoenvironmental Engineering, vol. 132, no. 2, 2006.

[15] A. Rahmani, M. Taiebat, W. D. L. Finn, and C. E. Ventura, "Evaluation of $p-y$ springs for nonlinear static and seismic soil-pile interaction analysis under lateral loading," Soil Dynamics and Earthquake Engineering, vol. 115, pp. 438-447, 2018.

[16] J. Dong, F. Chen, M. Zhou, and X. Zhou, "Numerical analysis of the boundary effect in model tests for single pile under lateral load," Bulletin of Engineering Geology and the Environment, vol. 77, no. 3, pp. 1057-1068, 2018.

[17] D. J. Zhou, W. A. Take, and M. D. Bolton, "Soil deformation measurement using particle image velocimetry (PIV) and photogrammetry," Géotechnique, vol. 53, no. 7, pp. 619-631, 2003.

[18] M. H. Bonab, Y. Sojoudi, and A. J. Puppala, "Study of strain wedge parameters for laterally loaded piles," International Journal of Geomechanics, vol. 13, no. 2, pp. 143-152, 2013.

[19] J. Otani, K. Pham, and J. Sano, "Investigation of failure patterns in sand due to laterally loaded pile using X-Ray CT," Soils and Foundations, vol. 46, no. 4, pp. 529-535, 2006.

[20] H. Yu, S. Peng, Q. Zhao et al., "Study on coefficient of horizontal resistance for gravel soil foundation on slopes," Rock and Soil Mechanics, vol. 38, no. 6, pp. 1682-1687, 2017. 